\title{
PENGARUH PERSEPSI DAN MODAL MINIMAL TERHADAP MINAT INVESTASI DI PASAR MODAL SYARIAH (Studi Pada Mahasiswa Fakultas Ekonomi dan Bisnis Islam IAIN Palu)
}

\author{
Nur Asriana ${ }^{1 *}$, Sofyan Bacmid², Syaifullah MS³, Abdul Jalii ${ }^{4}$ \\ 1,23,4 Jurusan Perbankan Syariah, Fakultas Ekonomi dan Bisnis Islam, UIN Datokarama Palu, \\ email: windyluande0211@gmail.com ; abdul_jaliil@iainpalu.ac.id
}

\section{ABSTRAK}

Investasi merupakan salah satu instrumen pembangunan yang di butuhkan oleh suatu negara dalam rangka meningkatkan kesejahteraan masyarakatnya, termasuk negara Indonesia. Tujuan penelitian ini adalah untuk mengetahui apakah ada pengaruh variabel persepsi dan modal minimal terhadap minat investasi di pasar modal syariah baik secara simultan maupun parsial. Pendekatan yang digunakan dalam penelitian ini adalah pendekatan kuantitatif. Teknik pengumpulan data dilakukan melalui observasi dan kuesioner (angket). Objek penelitian ini adalah masiswa Fakultas Ekonomi dan Bisnis Islam IAIN Palu angkatan 2017 baik yang sudah membuka account di pasar modal maupun yang belum. Hasil penelitian menunjukkan bahwa secara parsial terdapat pengaruh yang signifikan dari variabel persepsi dan modal minimal terhadap minat investasi di pasar modal syariah dengan nilai signifikansi (Sig.) kedua variabel tersebut yaitu 0,000 <0,05. Selain itu, secara simultan variabel persepsi dan modal minimal mempunyai pengaruh positif terhadap minat investasi dengan nilai signifikansi (Sig.) sebesar 0,000 $<0,05$. Begitu pula dengan membandingkan $F_{\text {hitung }}$ dan $F_{\text {tabel, }}$ maka

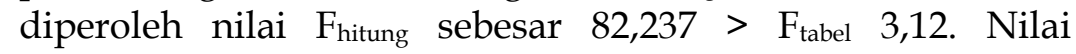
koefisien determinasi atau R Square adalah sebesar 0,684. Hal ini berarti bahwa variasi perubahan variabel minat investasi (Y) dipengaruhi oleh perubahan variabel persepsi (X1) dan modal minimal (X2) sebesar 68,4\%. Sedangkan, sisanya $(100 \%-68,4 \%=31,6 \%)$ dipengaruhi oleh faktor lain yang tidak diteliti atau diluar dari penelitian ini.
INFORMASI

ARTIKEL

Katakunci:

Persepsi, modal minimal, investasi, pasar modal syariah 


\section{PENDAHULUAN}

Sistem keuangan merupakan tatanan perekonomian dalam suatu negara yang berperan dan melakukan aktivitas dalam berbagai jasa keuangan yang di selenggarakan oleh lembaga keuangan. Tugas utama sistem keuangan adalah mengalihkan dana yang tersedia dari penabung kepada pengguna dana untuk kemudian digunakan membeli barang dan jasa-jasa untuk investasi sehingga ekonomi dapat tumbuh dan meningkatkan standar kehidupan. ${ }^{1}$

Selain itu, perkembangan ekonomi dan teknologi komunikasi yang sangat pesat memberikan begitu banyak kemudahan dalam sistem keuangan, terutama dalam dunia bisnis. Hal ini terlihat dengan banyaknya perusahaanperusahaan yang berdiri dan berkembang dengan memanfaatkan fasilitas teknologi. Perkembangan bisnis ini juga berdampak dengan meningkatnya daya saing antar perusahaan sehingga setiap perusahaan di tuntut untuk selalu mengembangkan strateginya. Salah satu bentuk perusahaan dalam menunjang kinerjanya adalah dengan bergabung di pasar modal, baik di pasar modal konvensional maupun pasar modal syariah. $^{2}$

Secara umum, Pasar modal merupakan suatu tempat bertemunya para penjual dan pembeli untuk melakukan transaksi dalam rangka

1 Andri Soemitra, Bank Dan Lembaga Keuangan Syariah (Jakarta: Prenadamedia Group, 2009), 17.

2 Siti Latifah," Pengaruh Pengetahuan, Modal Minimal, Dan Motivasi Investasi Terhadap Minat Mahasiswa Untuk Berinvestasi Di Pasar Modal Syariah",http:/ / repository.iainpurwokerto.ac.id /5030/. (16 September 2020). memperoleh modal. ${ }^{3}$ pasar modal syariah secara sederhana dapat diartikan sebagai pasar modal yang menerapkan prinsip-prinsip syariah dalam kegiatan transaksi ekonomi dan terlepas dari halhal yang dilarang seperti riba, perjudian, spekulasi dan lain-lain. ${ }^{4}$

Edukasi tentang pasar modal kepada masyarakat adalah hal yang penting karena bermanfaat untuk meningkatkan jumlah peminat agar berinvestasi di pasar modal. Oleh karena itu, pemerintah bekerjasama dengan Bursa Efek Indonesia (BEI) selaku pengelola penjualan efek di Indonesia melakukan upaya-upaya untuk terus meningkatkan investasi masyarakat di pasar modal. Salah satunya dengan modal minimal investasi melalui program "Yuk Nabung Saham", program ini merupakan sebuah kampanye untuk mengajak masyarakat Indonesia untuk berinvestasi di pasar modal melalui "share saving". Hanya dengan modal minimal Rp. 100.000,setiap bulannya, masyarakat dapat membeli saham melalui perusahaan sekuritas.

Dengan adanya kampanye "Yuk Nabung Saham" bertujuan untuk meningkatkan jumlah investor dan kesadaran masyarakat untuk berinvestasi di pasar modal. Kampanye ini juga bertujuan untuk memberikan motivasi, mengedukasi dan mengembangkan industri pasar modal,

${ }^{3}$ Malkan, M., Kurniawan, I., Nurdin, N., \& Noval, N. (2021). Pengaruh Pengetahuan Tentang Pasar Modal Syariah Terhadap Minat Investasi Saham di Pasar Modal Syariah Jurnal Ilmu Perbankan dan Keuangan Syariah, 3(1), 57-73.

${ }^{4}$ Andri Soemitra, Bank Dan Lembaga Keuangan Syariah (Jakarta: Prenadamedia Group, 2009), 111-112. 
sekaligus menambah investor baru yang menargetkan generasi muda khususnya mahasiswa. 5

Selain kampanye "Yuk Nabung Saham", BEI juga mengadakan program sosialisasi dan edukasi mengenai investasi di pasar modal, khususnya kepada kalangan akademisi kampus. Mahasiswa menjadi perhatian khusus dalam program edukasi pasar modal BEI. Guna mendukung program sosialisasi dan edukasi, maka BEI memberikan fasilitas dengan mendirikan galeri investasi di beberapa perguruan tinggi. Sebagaimana diketahui, galeri investasi BEI merupakan sarana untuk memperkenalkan pasar modal sejak dini kepada dunia akademisi. Galeri investasi berkonsep 3 in 1 yang merupakan kerjasama antara BEI, perguruan tinggi dan perusahaan sekuritas, dengan adanya galeri investasi diharapkan tidak hanya memperkenalkan pasar modal hanya dari sisi teori akan tetapi juga prakteknya. $^{6}$

Institut Agama Islam Negeri (IAIN) Palu merupakan salah satu perguruan tinggi islam negeri yang telah mempunyai galeri investasi. Dibukanya galeri investasi ini merupakan kerjasama antara Fakultas Ekonomi dan Bisnis Islam (FEBI) IAIN Palu, Bursa Efek Indonesia dan Philip Sekuritas. Oleh karena itu, mahasiswa dapat mulai untuk berinvestasi di pasar modal syariah untuk kondisi finansial yang

5 Siti Latifah," Pengaruh Pengetahuan, Modal Minimal, Dan Motivasi Investasi Terhadap Minat Mahasiswa Untuk Berinvestasi Di Pasar Modal Syariah",http:/ / repository.iainpurwokerto.ac.id /5030/. (16 September 2020).

${ }^{6}$ Ibid, hal 10 lebih baik di masa depan. Sebagai seorang mahasiswa, dana seringkali menjadi kendala utama dalam melakukan investasi terutama bagi mahasiswa yang penghasilannya didapat dari kiriman orang tuanya.

Jika dilihat secara umum, sumber keuangan mahasiswa diperoleh dari pemberian orang tua, beasiswa, dan pendapatan dari pekerjaan sampingan. Akan tetapi, syarat dan ketentuan dalam membuka akun investasi di pasar modal saat ini terbilang cukup mudah dengan modal minimal yaitu Rp. 100.000,sudah dapat membuka account. Dengan adanya kemudahan yang diberikan pihak sekuritas, diharapkan mampu memberikan motivasi bagi mahasiswa untuk berinvestasi.

Tulisan ini akan disusun sebagai berikut; setelah bagian pendahuluan ini akan dibahas kajian Pustaka. Pada bagian ketiga akan disajikan metode yang digunakan dalam penelitian ini. Selanjutnya dalam bagian ke empat disajikan hasil penelitian dan pembahasan. Sedangkan kesimpulan dan keterbatasan penelitian disajikan pada bagian kelima, yang kemudian diikuti dengan rekomendasi di bagian akhir tulisan ini.

\section{TINJAUAN PUSTAKA}

\subsection{Pengertian Persepsi}

Persepsi (dari bahasa latin perceptio, percipio) adalah tindakan menyusun, mengenali, dan menafsirkan informasi sensoris guna memberikan gambaran dan pemahaman tentang lingkungan. ${ }^{7}$

7 Persepsi,” Wikipedia Ensiklopedia Bebas. https://id.wikipedia.org/wiki/Persepsi (11 oktober 2020) 
Persepsi juga merupakan sebuah proses memahami lingkungan yang mengikutsertakan pengorganisasian dan penafsiran sebagai ransangan dalam sebuah pengalaman psikologi. Persepsi pada dasrnya ialah proses kognitif individu dalam memahami informasi tentang lingkungan sekitarnya melalui indera penglihatan, pendengaran, penghayatan, perasaan, dan penciuman. 8

\subsection{Proses Persepsi}

Menurut Kaidah (2015) Persepsi terbentuk karena adanya rangsangan yang diterima oleh panca indera, kemudian terbentuk sensasi yang cepat dan terwujud suatu perhatian yang membentuk tanggapan atau menyatakan bahwa proses persepsi terdiri dari : 9

1) Seleksi perceptual yaitu konsumen menangkap dan memilih stimulus berdasarkan pada psychological set yang dimiliki, yaitu berbagai informasi yang ada dalam memori konsumen.

2) Organisasi persepsi yaitu konsumen mengelompokkan informasi dari berbagai sumber kedalam pengertian yang menyeluruh untuk memahami lebih baik tentang produk dan jasa suatu perusahaan.

8 Syamsu Q. Badu dan Novianty Djafri. Kepemimpinan Dan Perilaku Organisasi (Gorontalo : Ideas Publishing, 2017), h. 59. (12 Oktober 2020)

9 Nur Kaidah, "Pengaruh Persepsi Mahasiswa Tentang Investasi Terhadap Minat Investasi Saham Di Pasar Modal Syariah (Studi Kasus Pada Mahasiswa Angkatan 2015 Fakultas Ekonomi Dan Bisnis Islam Dan Fakultas Syariah Universitas Islam Negeri Raden Intan Lampung)," Skripsi (Lampung : UIN Raden Intan Lampung, 2018), http://repository.radenintan.ac.id (12 Oktober 2020).
3) Interpretasi perceptual yaitu setiap stimuli yang menarik perhatian baik yang disadari atau tidak akan di interpretasikan oleh konsumen membentuk suatu persepsi. Stimuli atau rangsangan yang diterima oleh panca indera kita akan menimbulkan respon atau rangsangan berupa persepsi.

\subsection{Modal Minimal Investasi}

Modal merupakan sesuatu yang diperlukan untuk membiayai operasi perusahaan mulai dari berdiri sampai beroperasi. ${ }^{10}$ Untuk mendirikan atau menjalankan suatu usaha diperlukan sejumlah modal (uang) dan tenaga (keahlian). Modal dalam bentuk uang diperlukan untuk membiayai segala keperluan usaha, mulai dari biaya prainvestasi, pengurusan izin-izin, biaya investasi untuk pembelian aktiva tetap, sampai dengan modal kerja. ${ }^{11}$ Sementara itu, modal keahlian adalah keahlian dan kemampuan seseorang untuk mengelola dan menjalankan suatu usaha.

Pada bulan November 2015, kampanye Yuk Nabung Saham diluncurkan oleh Bursa Efek Indonesia. Program "Yuk Nabung Saham" dari BEI mencetuskan bahwa modal investasi minimal bagi untuk membuka Rekening Dana Nasabah (RDN) mengalami penurunan yakni sebesar Rp. 100.000.

10 Arini, "Pengaruh Pelayanan, Kebutuhan Modal dan Margin Keuntungan", 15.

11 Jalil, A., \& Hamzah, S. A. (2020). Pengaruh Bagi Hasil dan Kebutuhan Modal Terhadap Minat UMKM Mengajukan Pembiayaan Pada Lembaga Keuangan Syariah di Kota Palu. Jurnal Ilmu Perbankan dan Keuangan Syariah, 2(2), 178-198. 
Bagi para Pelajar dan Mahasiswa mereka dapat memulai investasi saham tanpa perlu khawatir dengan penggunaan modal yang besar. Modal minimal tersebut adalah setoran modal awal yang diberikan kepada perusahaan sekuritas untuk membuka akun rekening saham. Modal tersebut nantinya akan digunakan oleh investor untuk melakukan transaksi pembelian saham di pasar modal. ${ }^{12}$

Guna memberikan akses yang seluas-luasnya kepada masyarakat agar dapat masuk ke pasar modal maka Bursa Efek Indonesia (BEI) selaku penyelenggara perdagangan bursa saham telah mengeluarkan peraturan perubahan satuan perdagangan saham melalui keputusan No. Kep0071/BEI/11/2013, yaitu merubah satuan perdagangan dalam 1 lot yang tadinya 500 lembar saham menjadi 1 lot sama dengan 100 lembar saham. Dengan harga minimal saham yang diperdagangkan adalah Rp.50,- per lembar saham. Kemudian untuk membuka Rekening Dana Nasabah (RDN) ke pihak sekuritas hanya memerlukan persyaratan KTP dan mempunyai rekening bank dan modal minimal investasi yang disetor hanya sebesar Rp.100.000,-. Dengan perubahan satuan lot dan modal minimal investasi Rp.100.000,- maka investor pemula telah dapat membeli saham sebanyak 20 lot jika harga persatuan saham sebesar

12 Amalia Sundari, “Analisis Pengaruh Modal Minimal Dan Pemahaman Investasi Terhadap Minat Mahasiswa Berinvestasi Di Pasar Modal Ditinjau Dari Perspektif Ekonoomi Islam (Studi pada Mahasiswa Fakultas Ekonomi Dan Bisnis Islam UIN Raden Intan Lampung Angkatan Tahun 2014)," Skripsi (Lampung: UIN Raden Intan Lampung, 2019), http://repository.radenintan.ac.id (3 Oktober 2020)
Rp.50,-. Diharapkan dengan kemudahan dan ringannya modal minimal investasi ini dapat menarik minat masyarakat untuk mau berinvestasi di pasar modal. 13

\subsection{Minat Investasi}

Minat merupakan suatu dorongan yang kuat dalam diri seseorang terhadap sesuatu. Minat adalah rasa lebih suka dan ketertarikan pada suatu hal atau aktivitas, tanpa ada yang menyuruh. Salah satu factor yang mempengaruhi minat seseorang dalam berinvestasi adalah faktor inner urge yaitu rangsangan yang datang dari lingkungan atau ruang lingkup yang sesuai dengan keinginan atau kebutuhan seseorang akan mudah menimbulkan minat. Minat sangat besar pengaruhnya terhadap aktifitas yang dilakukan. ${ }^{14}$

Minat berinvestasi merupakan suatu perasaan tertarik akan kegiatan investasi dipasar modal dan merasa senang untuk melakukannya secara kontinyu. Perasaan tertarik tersebut bukan karena suatu paksaan tetapi karena keinginan dan rasa ketertarikan yang tinggi untuk mencapai tujuannya dalam hal ini untuk mendapatkan return di pasar modal. Minat investasi

13 Purboyo, Zulfikar, Teguh Wicaksono, "Pengaruh Aktifitas Galeri Investasi, Modal Minimal Investasi, Persepsi Resiko dan Persepsi Return Terhadap Minat investasi Saham Syariah (Studi pada Mahasiswa Uniska MAB Banjarmasin)," Jurnal Wawasan Manajemen, vol. 7 no. 2 (2019), 142. https:/ /jwm.ulm.ac.id/id (13 Oktober 2020) 14 Haris Nandar, Mustafa Kamal Rokan, M. Ridwan, "Faktor Yang Mempengaruhi Minat Mahasiswa Berinvestasi di Pasar Modal Syariah Melalui Galeri Investasi IAIN Zawiyah Cot KalaLangsa,"KITABAH, vol.2 no. 2 (JuliDesember 2018). 
merupakan pemusatan perhatian pada kegiatan investasi karena adanya rasa senang dan disertai keinginan untuk mempelajari, mengetahui dan membuktikan lebih lanjut terhadap investasi. Minat investasi muncul karena adanya pengetahuan dan informasi mengenai investasi dan pasar modal yang kemudian dilanjutkan untuk berpartisipasi secara langsung dalam rangka mencari pengalaman dan akhirnya timbul keinginan untuk memperhatikan pengalaman yang telah didapatkan tersebut serta mempunyai perasaan senang dan mempunyai keinginan untuk terlibat dalam kegiatan pengambilan risiko untuk menjalankan investasi dengan memanfaatkan peluang yang ada. ${ }^{15}$

\subsection{Faktor Penentu Minat}

Terdapat banyak hal yang dapat mempengaruhi timbulnya minat, baik yang berasal dari individu atau diri sendiri, atau pun dari lingkungan masyarakat. Ada 3 faktor utama yang membentuk minat yaitu : ${ }^{\prime \prime} 17$

15 Husna Fitri Amalia, "Pengaruh Return Dan risiko Terhadap Minat Investasi Mahasiswa Di Galeri Investasi Institut Agama Islam Negeri Ponorogo," Skripsi (Ponorogo : IAIN Ponorogo, 2019), http://etheses.iainponorogo.ac.id

16 Rahma Bellani Oktavindria Iranati, "Pengaruh Religiusitas, Kepercayaan, Pengetahuan, Dan Lokasi Terhadap Minat Masyarakat Menabung Di Bank Syariah (Studi Kasus Pada Masyarakat di Kota Tangerang Selatan)," Skripsi (Jakarta : UIN Syarif Hidayatullah Jakarta, 2017), http://repository.uinjkt.ac.id

17 Nurdin, N., Azizah, W. N., \& Rusli, R. (2020). Pengaruh Pengetahuan,Kemudahan dan Risiko Terhadap Minat Bertransaksi Menggunakan Finansial Technology (Fintech) Pada Mahasiswa Institut Agama Islam Negeri (IAIN) Palu Jurnal Ilmu Perbankan dan Keuangan Syariah, 2(2), 199-222.
1) Factor dari dalam individu, misalnya dorongan untuk makan maka akan membangkitkan minat untuk bekerja atau mencapai penghasilan, minat terhadap produksi makanan, dan lain-lain.

2) Factor motif social, dapat menjadi factor yang membangkitkan minat untuk melakukan suatu aktivitas. Misalnya minat terhadap pakaian timbul karena ingin mendapat persetujuan atau penerimaan dan perhatian dari orang lain. Minat belajar timbul karena ingin mendapat penghargaan dari masyarakat.

3) Factor emosional atau perasaan, minat mempunyai hubungan yang erat dengan emosi. Bila seseorang mendapat kesuksesan pada aktivitas yang dilakukannya, maka akan timbul rasa senang dan hal tersebut akan memperkuat rasa minat terhadap aktivitas tersebut.

\subsection{Investasi Dalam Perspektif Ekonomi Islam}

Investasi berasal dari Bahasa inggris investment dari kata dasar invest yang berarti menanam, atau istathmara dalam Bahasa arab, yang berarti menjadikan berbuah, berkembang dan bertambah jumlahnya. Secara istilah, investasi adalah barang yang tidak bergerak atau barang milik perseorangan atau perusahaan yang dimiliki dengan harapan untuk mendapatkan pendapatan periodic atau keuntungan atas penjualan dan pada 
umumnya dikuasai untuk periode yang relative Panjang. 18

Dalam system ekonomi Islam, investasi syariah tidak hanya membicarakan persoalan duniawi sebagaimana dikemukakan para ekonom sekuler. ${ }^{19}$ Terdapat unsur lain yang sangat menentukan berhasil tidaknya suatu investasi dimasa depan, yaitu ketentuan dan kehendak Allah SWT. Islam memadukan antara dimensi dunia dan akhirat. ${ }^{20}$ Setiap muslim harus berupaya meraih kebahagiaan di dunia dan akhirat. Islam mengajarkan bahwa semua perbuatan manusia yang bersifat vertical (hubungan dengan Allah) maupun horizontal (hubungan manusia dengan manusia) merupakan investasi yang akan dinikmati didunia dan akhirat. Karena perbuatan manusia dipandang sebagai investasi maka hasilnya aka nada yang beruntung dan ada pula yang merugi. Itulah yang disebut risiko yang harus dihadapi oleh investor. ${ }^{21}$

18 Elif Pardiansyah, "Investasi Dalam Perspektif Ekonomi Islam: Pendekatan Teoritis Dan Empiris," Economica: Jurnal Ekonomi Islam, vol.8 no. 2 (2017), 340.https://journal.walisongo.ac.id/index.php/ economica/article/view/1920 (7 Oktober 2020)

19 Nurdin, N., \& Yusuf, K. (2020). Knowledge management lifecycle in Islamic bank: the case of syariah banks in Indonesia. International Journal of Knowledge Management Studies, 11(1), 59-80. https://doi.org/10.1504/ijkms.2020.105073

20 Rusli, R., \& Nurdin, N. (2021). Understanding Indonesia millennia Ulama online knowledge acquisition and use in daily fatwa making habits. Education and Information Technologies. https://doi.org/10.1007/s10639021-10779-7

21 Diana Wiyanti, "Perspektif Hukum Islam Terhadap Pasar Modal Syariah Sebagai Alternatif
Investasi hanya boleh dilakukan pada instrumen keuangan yang sesuai dengan keuangan syariah Islam yaitu tidak mengandung riba. ${ }^{22^{\prime} 23}$ Untuk system perekonomian Indonesia saat ini, berdasar UU Pasar Modal hanya meliputi beberapa hal, yaitu instrument saham yang sudah melalui penawaran umum, pembagian deviden dan didasarkan pada tingkat laba usaha; penempatan dalam deposito pada Bank Umum Syariah; surat utang jangka panjang, yaitu berupa obligasi maupun surat utang jangka pendek yang telah lazim di diperdagangkan diantara lembaga keuangan syariah. Investasi juga dapat dilakukan pada efek-efek yang diterbitkan oleh pihak emiten yang jenis kegiatan usahanya tidak bertentangan dengan syariah islam seperti usaha perjudian, permainan yang tergolong judi, perdagangan yang dilarang seperti usaha keuangan konvensional (ribawi), asuransi konvensional, bank konvensional, usaha yang memproduksi, mendistribusi, serta memperdagangkan makanan dan minuman yang tergolong haram, usaha yang memproduksi, mendistribusi, serta

Investasi Bagi Investor," Jurnal Hukum IUS QUIA IUSTUM, vol. 20 no. 2 (April), 239-240. https://journal.uii.ac.id/ (8 Oktober 2020)

${ }^{22}$ Nurdin, N., Ningrum, R., Bachmid, S., \& Jalil, A. (2021). Pengaruh Manfaat, Kepercayaan dan Kemudahan Penggunaan Terhadap Minat Nasabah Menggunakan Mobile Banking di Bank Mega Syariah Cabang Palu Jurnal Ilmu Perbankan dan Keuangan Syariah, 3(1), 30-45.

${ }^{23}$ Marzuki, M., \& Nurdin, N. (2020). The Influence of Halal Product Expectation, Social Environment, and Fiqih Knowledge on Intention to Use Shariah Financial Technology Products. International Journal of Innovation, Creativity and Change, 13(1), 171-193. 
menyediakan barang-barang jasa yang merusak moral dan bersifat mudarat. ${ }^{24}$

Selain itu, jenis kegiatan emiten yang dianggap tidak layak di investasikan ialah apabila tingkat pencapaian bunga bersih beserta pendapatan non halal, baik dari emiten maupun anak perusahaannya, terhadap pendapatan/penjualan seluruhnya diatas 15\%. Begitu pula, apabila suatu emiten memiliki penyertaan saham lebih dari $50 \%$ di perusahaan yang usahanya bertentangan dengan syariah Islam, maka jenis kegiatan emiten seperti ini juga dianggap bertentangan dengan syariah Islam. 25

Selain memperhatikan emiten, harus memperhatikan pula jenis-jenis transaksi investasi sebab ada beberapa jenis transaksi yang dilarang. Pemilihan dan pelaksanaan transaksi investasi harus dilaksanakan menurut prinsip kehati- hatian (prudential management/ihtiyaath) serta tidak boleh melakukan spekulasi yang didalamnya mengandung unsur gharar, termasuk tindakan melakukan penawaran palsu (najsy), melakukan penjualan atas barang yang belum dimiliki (short selling), menyebarkan informasi yang menyesatkan atau memakai informasi orang dalam untuk memperoleh keuntungan transaksi yang dilarang (insider trading), melakukan penempatan investasi pada perusahaan yang memiliki rasio (nisbah) utang yang diatas kelaziman perusahaan pada industry sejenis.

24 Sakinah, "Investasi Dalam Islam," Iqtishadia : Jurnal Ekonomi Dan Perbankan Syariah, Vol.1no.2 (Desember 2014), 255. http:/ / ejournal.stainpamekasan.ac.id

(7 Oktober 2020)

25 Ibid, hal. 239
Nisbah utang terhadap modal yang digunakan untuk mengetahui bagaimana struktur pembiayaan suatu emiten, apakah emiten tersebut sangat bergantung dengan pembiayaan dari utang yang pada intinya merupakan pembiayaan yang mengandung unsur riba. Nisbah utang terhadap modal merupakan perbandingan antara utang terhadap total nilai modal termasuk cadangan, laba ditahan, dan utang dari pemegang saham. Apabila suatu emiten memiliki nisbah utang terhadap modal lebih dari $81 \%$ (utang 45\%, modal 55\%), maka emiten tersebut dapat dianggap bertentangan dengan syariah Islam. Nisbah yang diizinkan (diperbolehkan) akan ditentukan perkembangannya setiap waktu oleh Dewan Syariah Nasional (DSN). ${ }^{26}$

Berikut ini adalah beberapa aspek yang harus dimiliki dalam berinvestasi menurut perspektif Islam :27

1) Aspek material atau finansial. Artinya suatu bentuk investasi hendaknya menghasilkan manfaat finansial yang kompetitif dibandingkan dengan bentuk investasi lainnya.

2) Aspek kehalalan. Artinya suatu bentuk investasi harus terhindar dari bidang maupun prosedur yang subhat atau haram. Suatu bentuk investasi yang tidak halal hanya akan membawa pelakunya kepada kesesatan serta sikap dan perilaku

${ }^{26}$ Ibid, Hal. 260

27 Elif Pardiansyah, "Investasi Dalam Perspektif Ekonomi Islam: Pendekatan Teoritis Dan Empiris," Economica: Jurnal Ekonomi Islam, vol.8 no. 2 (2017), 341-342. https://journal.walisongo.ac.id

(7 Oktober 2020) 
destruktif (darurah) secara individu maupun social.

3) Aspek social dan lingkungan. Artinya suatu bentuk investasi hendaknya memberikan kontribusi positif bagi masyarakat banyak dan lingkungan sekitar, baik untuk generasi saat ini maupun yang akan datang.

4) Aspek pengharapan kepada ridho Allah SWT. Artinya suatu bentuk investasi tertentu dipilih adalah dalam rangka mencapai ridha Allah SWT.

2.7 Faktor-Faktor Yang Di Pertimbangkan Dalam Berinvestasi

Terdapat beberapa hal penting yang harus diketahui sebelum melakukan investasi diantarnya: 28

1) Tujuan Investasi

Investor harus menentukan tujuan yang ingin dicapai. Umumnya, tujuan utama orang berinvestasi adalah mencari keuntungan atau tambahan penghasilan pada masa yang akan datang.

2) Kenali Karakter

Umumnya karakter investor terdiri dari 3 karakter, yaitu pengambil risiko (risk taker), penghindar risiko (risk avoider), dan netral. Karakter investor akan berpengaruh terhadap perilaku dalam berinvestasi.

3) Pelajari keuangan (Modal)

Besar kecilnya modal tergantung dari kebutuhan dan kemampuan seorang investor. Semakin besar kebutuhan

28 Siti Rahma Hasibuan, "Minat Investasi Mahasiswa Untuk Berinvestasi Di Pasar Modal Syariah (Studi Kasus di Galeri Investasi UIN Sumatera Utara Periode 2017-2018)," Skripsi (Medan: UIN Sumatera

Utara,2018/2019)http:/ / repository.uinsu.ac.id.

Diakses 13 Oktober 2020 untuk modal, maka semakin besar pula keuntungan yang diharapakn nantinya.

4) Jenis investasi yang di Pilih

Untuk memilih jenis investasi, investor perlu membuat rencana tentang pengeluaran jangka waktu investasi, pendek, menengah, panjang. Setiap pengeluaran membutuhkan sejumlah uang yang sumber pendapatannya harus dicari. Dengan mengetahui jumlah pengeluaran, baik pengeluaran jangka pendek maupun jangka panjang, investor dapat menentukan jenis investasi yang ingin dilakukan. Jangka waktu investasi dapat membantu dalam menentukan berapa besar resiko yang dapat ditanggung. Pada umumnya, orang yang berinvestasi untuk jangka panjang menanggung resiko yang lebih besar. Hal ini disebabkan investasi saham mengalami fluktuasi yang tinggi dari waktu ke waktu.

5) Keuntungan dan Risiko

Besar kecilnya keuntungan dari hasil investasi tergantung dari besar kecilnya tujuan dan kemampuan seseorang untuk mewujudkannya dan harus ada keselarasan antara keuntungan dan kemampuan yang dimiliki dalam menentukan tujuan. Resiko selalu mengikuti investasi, baik investasi yang mendapatkan keuntungan besar dan kecil.

6) Evaluasi Kinerja Keuangan

Memilih satu jenis investasi berdasarkan keuntungan yang tinggi. Data historis membuktikan bahwa investasi yang mempunyai kinerja yang bagus pada masa lalu tidak selalu memberikan kinerja sama pada masa yang akan datang. 
7) Lakukan diversifikasi

Salah satu untuk mencapai tingkat keuntungan yang baik secara konsisten adalah diversifikasi atau berinvestasi pada lebih dari satu investasi. Diversifikasi merupakan sebuah cara untuk mengendalikan resiko karena walaupun berinvestasi pada beberapa jenis investasi beresiko tinggi, bila nilai salah satu investasi tersebut menurun, investasi yang lain mungkin naik.

\section{METODE PENELITIAN}

Pendekatan yang digunakan dalam penelitian ini adalah pendekatan kuantitatif, karena penelitian ini berfokus untuk mengetahui pengaruh variabel persepsi dan variabel modal minimal terhadap minat investasi di Pasar Modal Syariah melalui perolehan data berbentuk angka-angka yang selanjutnya akan dilakukan analisis melalui statistik.

Penelitian ini adalah penelitian lapangan (field research) yaitu penelitian yang dilakukan secara langsung dilapangan. ${ }^{29}$ Data dalam penelitian ini diambil dengan melakukan survei langsung kepada mahasiswa Fakultas Ekonomi dan Bisnis Islam (FEBI) dan Galeri Investasi yang ada dilingkungan IAIN Palu, tepatnya di Fakultas Ekonomi dan Bisnis Islam.

Populasi dalam penelitian ini adalah seluruh mahasiswa pada Fakultas Ekonomi dan Bisnis Islam, baik jurusan Ekonomi Syariah maupun Perbankan

29 Nurdin, N. (2018). Institutional Arrangements in E-Government Implementation and Use: A Case Study From Indonesian Local Government. International Journal of Electronic Government Research (IJEGR), 14(2), 44-63. https://doi.org/10.4018/ijegr.2018040104
Syariah angkatan 2017 dengan jumlah mahasiswa sebanyak 359 orang.

Adapun teknik pengambilan sampel pada penelitian ini adalah menggunakan purposive sampling, yaitu salah satu teknik pengambilan sampel dengan pertimbangan khusus agar data dari hasil penelitian yang dilakukan menjadi lebih representatif.

Teknik analisis data yang digunakan dalam penelitian ini adalah analisis kuantitatif dengan menggunakan Statistical Package for Social Science (SPSS) 23 for windows sebagai alat ukurnya. 30

Analisa data dilakukan dengan tahap uji validitas, reabilitas, uji asumsi klasik, dan uji regresi. Untuk pembuktian hipotesis penulis menggunakan uji $\mathrm{F}$ dan uji $\mathrm{T}$ dan uji $\mathrm{R}$ Square. Untuk mengetahui apakah variabel independen berpengaruh signifikan terhadap variabel dependen, dilakukan perbandingan antara $F_{\text {hitung }}$ dengan $F_{\text {tabel }}$ pada tingkat kepercayaan $0,05.31$

\section{HASIL DAN PEMBAHASAN}

4.1 Gambaran Umum Fakultas Ekonomi dan Bisnis Islam IAIN Palu

Berdasarkan keputusan Menteri Agama Republik Indonesia Nomor 100/IN.13/KP.07.6/02/2019 tanggal 14 Februari 2019 telah diangkat dalam jabatan Dekan Fakultas Ekonomi dan Bisnis Islam Institut Agama Islam Negeri Palu dan telah dilantik oleh

30 Yusuf Adam, "Pengaruh Gaya Kepemimpinan Dan Motivasi Kerja Terhadap Kinerja Karyawan Pada Bank Mandiri KCP Palu Imam Bonjol" (Skripsi Jurusan Perbankan Syariah, IAIN Palu, Palu, 2020), 37-38.

31 Sudaryono, Metodologi Penelitian. (Depok : RajaGrafindo Persada, 2013), 154. 
Rektor Institut Agama Islam Negeri Palu pada tanggal 15 Februari 2019.32

Penelitian ini dilakukan di Institut Agama Islam Negeri (IAIN) Palu pada Fakultas Ekonomi dan Bisnis Islam (FEBI) yang beralamatkan di Jln. Diponegoro No. 23 Palu, Sulawesi Tengah.

Fakultas Ekonomi dan Bisnis Islam mempunyai visi misi sebagai berikut :

1. Visi

Mewujudkan Fakultas Ekonomi dan Bisnis Islam yang bermutu dan berdaya saing secara global.

2. Misi

1) Memperluas dan memperdalam kajian ilmu keislaman dan ilmu pengetahuan umum secara integratif.

2) Meningkatkan kualitas penyelenggaraan pendidikan berbasis iman, ilmu dan kearifan lokal.

3) Peningkatan kualitas layanan akademik dan administratif berbasis IT.

4) Memperluas jaringan kerjasama dengan institusi terkait dibidang keilmuan, kebudayaan, dan teknologi dalam dan luar negeri.

\subsection{Deskripsi Hasil Penelitian}

4.3.1 Deskripsi Kuesioner dan Sampel Penelitian

Data penelitian diambil menggunakan instrumen kuesioner yang disebarkan kepada mahasiswa jurusan Ekonomi Syariah dan Perbankan Syariah angkatan 2017 yang terdiri dari 79 mahasiswa sampel

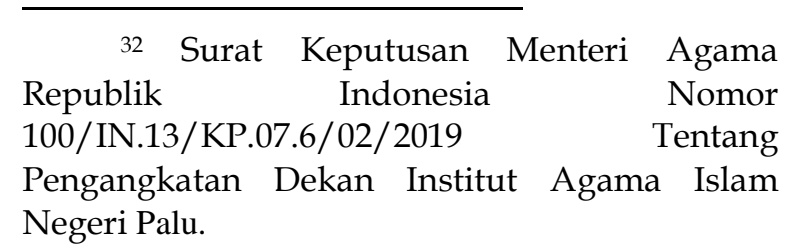

penelitian dari populasi 359 mahasiswa melalui Google Form.

Jumlah sampel yang digunakan dalam penelitian ini adalah 79 mahasiswa dari Fakultas Ekonomi dan Bisnis Islam (FEBI) angkatan 2017 IAIN Palu. Data responden dalam penelitian ini dijelaskan dalam tabel sebagai berikut :

\begin{tabular}{|c|l|r|l|l|l|}
\hline \multirow{2}{*}{ No } & \multirow{2}{*}{ Jurusan } & \multicolumn{2}{|c|}{$\begin{array}{c}\text { Jenis } \\
\text { Kelamin }\end{array}$} & \multirow{2}{*}{ Jumlah } & $\begin{array}{c}\text { Presenta } \\
\text { se }\end{array}$ \\
\cline { 3 - 6 } & Lk & Pr & & $26,6 \%$ \\
\hline 2 & $\begin{array}{l}\text { Ekonomi } \\
\text { Syariah }\end{array}$ & 6 & 15 & 21 & $73,4 \%$ \\
\hline $\begin{array}{l}\text { Perbanka } \\
\text { n Syariah }\end{array}$ & 19 & 39 & 58 & $100 \%$ \\
\hline \multicolumn{2}{|c|}{ Jumlah } & 25 & 54 & 79 & \\
\end{tabular}

Tabel 1 Karakteristik Responden

\subsection{Uji Instrumen penelitian}

4.4.1 Uji Validitas

Hasil Uji Validitas Instrumen

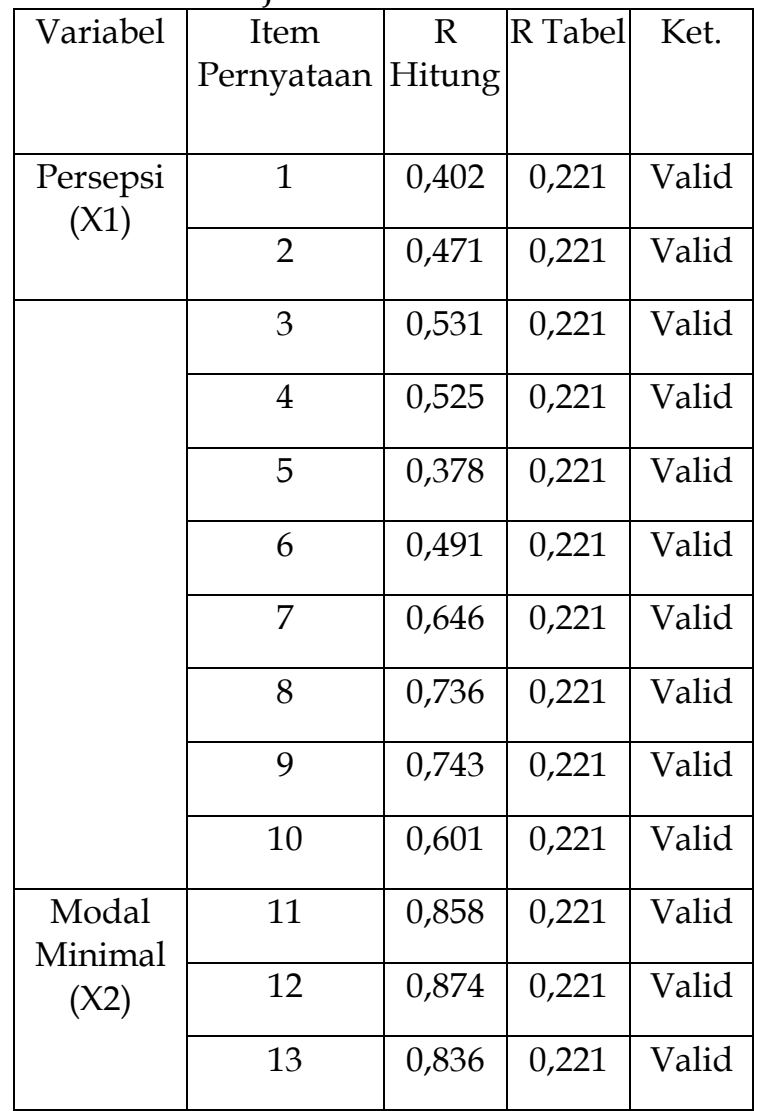




\begin{tabular}{|c|c|c|c|c|}
\hline & 14 & 0,329 & 0,221 & Valid \\
\cline { 2 - 5 } & 15 & 0,832 & 0,221 & Valid \\
\cline { 2 - 5 } & 16 & 0,753 & 0,221 & Valid \\
\cline { 2 - 5 } $\begin{array}{c}\text { Minat } \\
\text { Investasi } \\
(Y)\end{array}$ & 17 & 0,814 & 0,221 & Valid \\
\cline { 2 - 5 } & 18 & 0,847 & 0,221 & Valid \\
\cline { 2 - 5 } & 20 & 0,758 & 0,221 & Valid \\
\cline { 2 - 5 } & 21 & 0,521 & 0,221 & Valid \\
\hline
\end{tabular}

Sumber Data: Output Spss 23

Berdasarkan tabel diatas, terlihat bahwa nilai rhitung dari ketiga variabel yang diteliti diatas dinyatakan Valid karena $r_{\text {hitung }}$ lebih besar dari $r_{\text {tabel }}$.

\subsubsection{Uji Reabilitas}

Hasil Uji Reliabilitas Instrumen

\begin{tabular}{|c|c|c|c|}
\hline Variabel & $\begin{array}{c}\text { Reliability } \\
\text { Coefficiens }\end{array}$ & $\begin{array}{c}\text { Cronbach } \\
\text { Alpha }\end{array}$ & Ket. \\
\hline $\begin{array}{c}\text { Persepsi } \\
(X 1)\end{array}$ & 10 Item & 0,738 & Reliabel \\
\hline $\begin{array}{c}\text { Modal } \\
\text { Minimal } \\
(X 2)\end{array}$ & 3 Item & 0,808 & Reliabel \\
\hline $\begin{array}{c}\text { Minat } \\
\text { Investasi } \\
(Y)\end{array}$ & 8 Item & 0,859 & Reliabel \\
\hline
\end{tabular}

\section{Sumber Data: Output SPSS 23}

Berdasarkan tabel diatas, dapat diketahui bahwa masing-masing variabel memiliki Cronbach's Alpha $(\alpha)$ lebih dari 0,60 $(\alpha>0,60)$. Berdasarkan hasil dari uji reliabilitas tersebut dapat dinyatakan bahwa variabel persepsi (X1), modal minimal (X2) dan minat investasi $(\mathrm{Y})$ adalah reliabel.

4.5 Uji Asumsi Klasik

4.5.1 Uji normalitas

Hasil Uji Normalitas KolmogorovSmirnov
One-Sample Kolmogorov-Smirnov Test

\begin{tabular}{|ll|r|}
\hline & & $\begin{array}{r}\text { Unstandardize } \\
\text { dResidual }\end{array}$ \\
Normal & Mean & 79 \\
Parametersa, & & .0000000 \\
$\mathrm{~b}$ & Std. & \\
& Deviation & .67250816 \\
Most & Absolute & .091 \\
Extreme & & \\
Differences & & .091 \\
& Positive & -.071 \\
Test Statistic & & .091 \\
Asymp. Sig. & & $.168 \mathrm{c}$ \\
(2-tailed) & & \\
& & Negative \\
\hline
\end{tabular}

Sumber:Data Ouput SPSS 23

Dari tabel diatas, dapat dilihat bahwa nilai Unstandardized Residual adalah 0,168. Dengan demikian, dapat disimpulkan bahwa instrumen penelitian terdistribusi dengan normal karena nilai Unstandardized Residual > 0,05 .

\subsubsection{Uji multikoliniearitas}

Hasil Uji Multikoliniearitas

\begin{tabular}{|c|c|c|}
\hline \multirow{2}{*}{ Model } & \multicolumn{2}{|c|}{ Collinearity Statistics } \\
\cline { 2 - 3 } & Tolerance & VIF \\
\hline 1 (Constant) & & \\
\hline Persepsi & 0,791 & 1,264 \\
\hline $\begin{array}{c}\text { Modal } \\
\text { Minimal }\end{array}$ & 0,791 & 1,264 \\
\hline
\end{tabular}

Sumber : Data Output SPSS 23

Berdasarkan

hasil uji multikoliniearitas yang terdapat pada tabel diatas, model regresi bebas dari adanya multikoliniearitas. Hal ini dapat dilihat bahwa kedua variabel independen yaitu variabel persepsi (X1) 
dan variabel modal minimal (X2) memiliki nilai Tolerance lebih dari 0,100. Selain itu, hasil perhitungan Variance Inflation Factor (VIF) juga menunjukkan hal yang sama yaitu tidak ada satu pun variabel independen yang memiliki nilai VIF lebih dari 10,00. 33

\subsubsection{Uji heterokedastisitas}

\section{Hasil Uji heterokedastisitas}

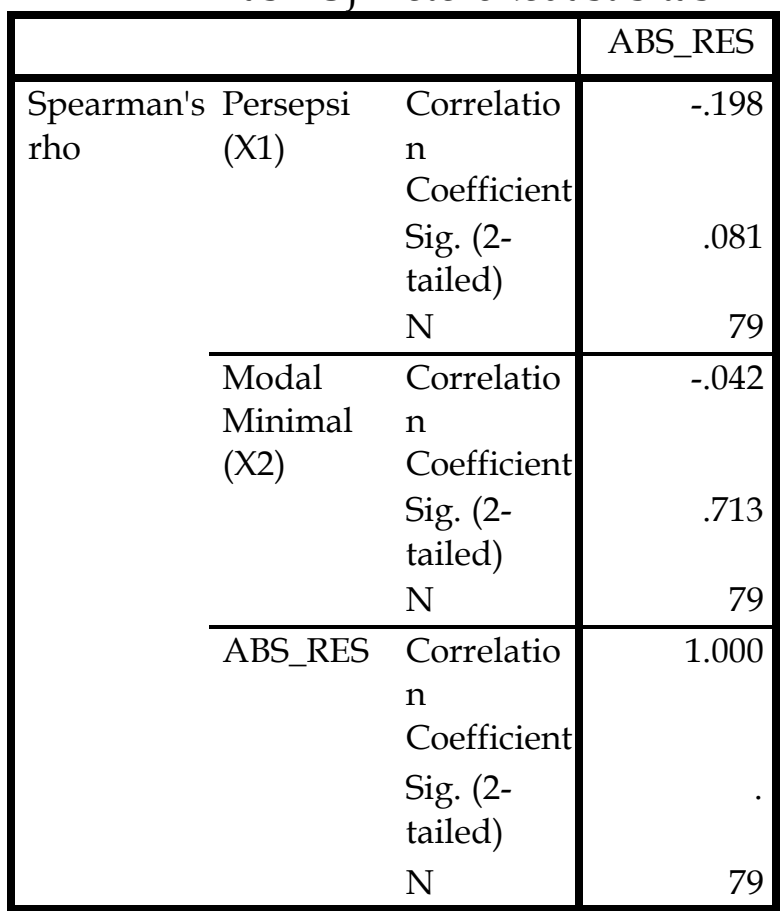

Sumber: Data Output SPSS 23

\section{Berdasarkan}

hasil

uji

heterokedastisitas pada tabel 4.9 diatas, dapat dilihat bahwa nilai signifikansi (Sig.) kedua variabel independen memiliki nilai lebih dari 0,05 yang berarti bahwa tidak terjadi gejala heterokedatisitas.

33 Uji Multikolinearitas dengan Melihat Nilai Tolerance dan VIF SPSS," Situs SPSS Indonesia. https://www.spssindonesia.com (08 April 2021)
4.6 Analisis Regresi Linear Berganda

Hasil Analisis Regresi Berganda

\begin{tabular}{|l|r|r|r|r|r|}
\hline & \multicolumn{2}{|c|}{$\begin{array}{c}\text { Unstandardized } \\
\text { Coefficients }\end{array}$} & $\begin{array}{c}\text { Standardized } \\
\text { Coefficients }\end{array}$ & & \\
\cline { 2 - 5 } Model & $\mathrm{B}$ & $\begin{array}{r}\text { Std. } \\
\text { Error }\end{array}$ & Beta & $\mathrm{t}$ & Sig. \\
\hline 1 (Constant) & -1.280 & 3.310 & & -.387 & .700 \\
$\begin{array}{l}\text { Persepsi } \\
\text { (X1) }\end{array}$ & .381 & .089 & .312 & 4.304 & .000 \\
$\begin{array}{l}\text { Modal } \\
\text { Minimal } \\
\text { (X2) }\end{array}$ & 1.435 & .163 & .636 & 8.776 & .000 \\
\hline
\end{tabular}

Sumber: Data Output SPSS 23

Berdasarkan hasil analisis regresi linear berganda diatas, kemudian dimasukkan kedalam model persamaan regresi berganda sebagai berikut.

$\mathrm{Y}=\mathrm{a}+\mathrm{b} 1 \mathrm{x} 1+\mathrm{b} 2 \mathrm{x} 2+\mathrm{e}$

$\mathrm{Y}=(-1,280)+0,381 \times 1+1,435 \times 2+\mathrm{e}$

Dari persamaan diatas, dapat dilihat bahwa kedua variabel independen (Persepsi dan Modal Minimal) memiliki arah yang positif terhadap variabel dependen (Minat Investasi). Hasil persamaan diatas dapat dijelaskan sebagai berikut.

1) Nilai a (angka konstan) $=-1,280$ yang berarti bahwa minat investasi akan meningkat sebesar -1,280 jika variabel persepsi dan modal minimal konstan.

2) Koefisen regresi persepsi (X1) bernilai positif sebesar 0,381 yang berarti bahwa setiap terjadi peningkatan satu satuan variabel persepsi (X1) maka akan meningkatkan minat investasi sebesar 0,381 jika variabel lain dianggap konstan.

3) Koefisen regresi modal minimal (X2) bernilai positif sebesar 1,435 yang berarti bahwa setiap terjadi peningkatan satu satuan variabel modal minimal (X2) maka akan meningkatkan minat investasi 
sebesar 1,435 jika variabel lain dianggap konstan.

4.7 Hasil Pengujian Hipotesis

4.7.1 Uji F (Uji Simultan)

Hasil Uji F (Uji

Simultan)

ANOVAa

\begin{tabular}{|l|r|r|r|c|c|}
\hline Model & \multicolumn{1}{|c|}{$\begin{array}{c}\text { Sum of } \\
\text { Squares }\end{array}$} & df & $\begin{array}{c}\text { Mean } \\
\text { Square }\end{array}$ & F & Sig. \\
\hline 1 Regression & 1205.635 & 2 & 602.817 & 82.237 & $.000^{\mathrm{b}}$ \\
Residual & 557.099 & 76 & 7.330 & & \\
Total & 1762.734 & 78 & & & \\
\hline
\end{tabular}

a. Dependent Variable: Minat Investasi

(Y)

a. Predictors: (Constant), Modal Minimal (X2), Persepsi (X1)

Sumber: Data Output SPSS 23

Berdasarkan tabel diatas, diperoleh

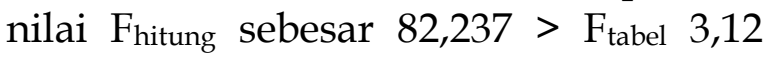
dengan signifikansi (Sig.) sebesar 0,000 < 0,05 . Dengan demikian, hasil dari uji $F$ (uji simultan) berarti bahwa variabel persepsi (X1) dan variabel modal minimal (X2) secara simultan berpengaruh terhadap variabel minat investasi $(Y)$.

\subsubsection{Uji T (Uji Parsial) Hasil Uji T (Uji Parsial)}

\section{Coefficients $^{a}$}

\begin{tabular}{|l|r|r|r|r|r|}
\hline & \multicolumn{2}{|c|}{$\begin{array}{c}\text { Unstandardized } \\
\text { Coefficients }\end{array}$} & $\begin{array}{c}\text { Standardized } \\
\text { Coefficients }\end{array}$ & & \\
\cline { 2 - 5 } Model & $\mathrm{B}$ & $\begin{array}{r}\text { Std. } \\
\text { Error }\end{array}$ & \multicolumn{1}{|c|}{ Beta } & \multirow{2}{*}{ Sig. } \\
\hline 1 (Constant) & -1.280 & 3.310 & & -.387 & .700 \\
$\begin{array}{l}\text { Persepsi } \\
\text { (X1) }\end{array}$ & .381 & .089 & .312 & 4.304 & .000 \\
$\begin{array}{l}\text { Modal } \\
\text { Minimal } \\
\text { (X2) }\end{array}$ & 1.435 & .163 & .636 & 8.776 & .000 \\
\hline
\end{tabular}

a. Dependent Variable: Minat Investasi (Y)

\section{Sumber: Data Output SPSS 23}

Berdasarkan hasil perhitungan uji $\mathrm{T}$ pada tabel diatas, dapat dilihat bahwa :
1) Variabel persepsi (X1) memiliki nilai Thitung 4,304 < Ttabel 1,991 dan memiliki nilai signifikansi (Sig.) 0,000 $<0,05$. Nilai dari hasil uji $\mathrm{T}$ untuk variabel persepsi (X1) berarti bahwa secara parsial variabel persepsi (X1)memberikan pengaruh secara signifikan terhadap variabel minat investasi $(Y)$.

2) Variabel modal minimal (X2) memiliki nilai Thitung 8,776 < Ttabel 1,991 dan memiliki nilai signifikansi (Sig.) 0,000<0,05. Nilai dari hasil uji $\mathrm{T}$ untuk variabel modal minimal (X2) berarti bahwa secara parsial variabel modal minimal (X2) memberikan pengaruh secara signifikan terhadap variabel minat investasi (Y). 4.7.3 Analisis Koefisien Determinasi Nilai Koefisien Determinasi

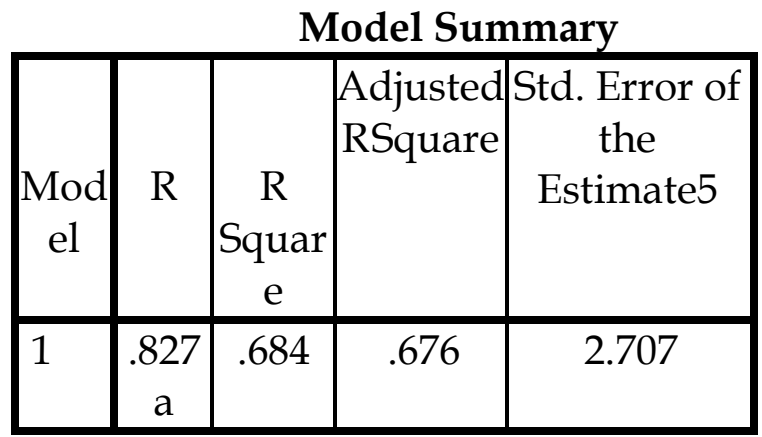

a. Predictors: (Constant), Modal Minimal (X2), Persepsi (X1)

Berdasarkan tabel output SPSS diatas, diketahui bahwa nilai koefisien determinasi atau $\mathrm{R}$ Square adalah sebesar 0,684. Hal ini berarti bahwa variasi perubahan variabel minat investasi (Y) dipengaruhi oleh perubahan variabel persepsi (X1) dan modal minimal (X2) sebesar 68,4\%. Sedangkan, sisanya $(100 \%-68,4 \%=$ $31,6 \%)$ dipengaruhi oleh faktor lain yang tidak diteliti atau diluar dari penelitian ini. 


\subsection{Pembahasan Hasil Penelitian}

Hasil pengujian hipotesis yang terdiri dari uji $\mathrm{F}$ (uji simultan) dan uji $\mathrm{T}$ (uji parsial), dengan membandingkan Fhitung dan $F_{\text {tabel }}$ menunjukan bahwa variabel persepsi (X1) dan variabel modal minimal (X2) secara simultan berpengaruh terhadap variabel minat investasi (Y) maka hipotesis $\mathrm{H} 3$ diterima dan $\mathrm{HO}$ ditolak.

Hasil uji T untuk variabel persepsi (X1) menunjukan bahwa secara parsial variabel persepsi (X1) memberikan pengaruh secara positif dan signifikan terhadap variabel minat investasi $(Y)$. Hasil penelitian ini sejalan dengan penelitian yang dilakukan oleh Nur Kaidah dalam skripsi yang berjudul "Pengaruh Persepsi Mahasiswa Tentang

Investasi Terhadap Minat Berinvestasi Saham Di Pasar Modal Syariah (Studi Kasus Pada Mahasiswa Angkatan 2015 Fakultas Ekonomi Dan Bisnis Islam Dan Fakultas Syariah Universitas Islam Negeri Raden Intan Lampung)" menunjukkan bahwa untuk Fakultas Ekonomi Dan Bisnis Islam persepsi yang muncul dari mahasiswa mampu mempengaruhi minat investasi saham menjadi meningkat sebesar $68 \% .34$

Pengujian uji T untuk variabel modal minimal (X2) menunjukan hasil bahwa secara parsial variabel modal minimal (X2) memberikan pengaruh positif dan

34 Nur Kaidah, "Pengaruh Persepsi Mahasiswa Tentang Investasi Terhadap Minat Investasi Saham Di Pasar Modal Syariah (Studi Kasus Pada Mahasiswa Angkatan 2015 Fakultas Ekonomi Dan Bisnis Islam Dan Fakultas Syariah Universitas Islam Negeri Raden Intan Lampung)", Skripsi (Lampung: Universitas Islam Negeri Raden Intan Lampung, 2018), http://repository.radenintan.ac.id signifikan terhadap variabel minat investasi (Y). Hasil penelitian ini sejalan dengan penelitian yang dilakukan oleh M. Samsul Haidir dalam jurnalnya yang berjudul "Pengaruh Pemahaman Investasi, Dengan Modal Minimal Dan Motivasi Terhadap Minat Mahasiswa Dalam Melakukan Investasi Di Pasar Modal Syariah" menunjukkan bahwa variable. 35

\section{KESIMPULAN}

Hasil penelitian menunjukkan bahwa variabel persepsi (X1) secara parsial berpengaruh signifikan terhadap minat investasi (Y). Hal ini dibuktikan dengan hasil pengujian menggunakan SPSS 23 for windows menunjukkan variabel persepsi (X1) memiliki nilai $\mathrm{T}_{\text {hitung }} 4,304$ $>\mathrm{T}_{\text {tabel }} 1,991$ dan memiliki nilai signifikansi (Sig.) 0,000 < 0,05 sehingga dapat disimpulkan bahwa hipotesis H1 diterima yaitu adanya pengaruh variabel persepsi (X1) terhadap minat investasi (Y).

Selanjutnya hasil penelitian variabel modal minimal (X2) secara parsial berpengaruh signifikan terhadap minat investasi (Y). Hal ini dapat dibuktikan dengan hasil uji yang dilakukan menunjukkan variabel modal minimal (X2) memiliki nilai Thitung 8,776 > Ttabel 1,991 dan memiliki nilai signifikansi (Sig.) 0,000<0,05 . sehingga dapat disimpulkan bahwa hipotesis H2 diterima yaitu adanya pengaruh

35 M. Samsul Haidir, "Pengaruh Pemahaman Investasi, Dengan Modal Minimal Dan Motivasi Terhadap Minat Mahasiswa Dalam Melakukan Investasi Di Pasar Modal Syariah", Jurnal Istiqro: Jurnal Hukum Islam, Ekonomi Dan Bisnis, Vol. 5 no. 2 (July 2019), 11. http://ejournal.iaida.ac.id 
variabel modal minimal (X2) terhadap minat investasi $(Y)$.

Hasil penelitian menunjukkan bahwa variabel persepsi (X1) dan modal minimal (X2) secara simultan mempunyai pengaruh yang positif terhadap minat investasi $(Y)$. Hal ini dibuktikan dengan hasil uji F (uji simultan) menunjukkan nilai signifikansi (Sig.) sebesar 0,000 0,05. sehingga hipotesis $\mathrm{H} 3$ diterima dan $\mathrm{H} 0$ ditolak.

\section{PENELITIAN KEDEPAN}

Bagi teman-teman mahasiswa yang berminat untuk berinvestasi khususnya mahasiswa Fakultas Ekonomi dan Bisnis Islam IAIN Palu angkatan 2017 sebaiknya lebih meningkatkan pemahaman tentang investasi di pasar

\section{DAFTAR PUSTAKA}

Adam, Yusuf. "Pengaruh Gaya Kepemimpinan Dan Motivasi Kerja Terhadap Kinerja Karyawan Pada Bank Mandiri KCP Palu Imam Bonjol" Skripsi tidak diterbitkan, Jurusan Perbankan Syariah, IAIN Palu, Palu, 2020

Badu, Syamsu Q. dan Novianty Djafri. Kepemimpinan Dan Perilaku Organisasi (Gorontalo : Ideas Publishing, 2017. https://www.pdfdrive.com/novia nty- djafri-buku-kepemimpinandan-perilaku-organisasie59768821.html

Haidir, M. Samsul. "Pengaruh Pemahaman Investasi, Dengan Modal Minimal Dan Motivasi Terhadap Minat Mahasiswa Dalam Melakukan Investasi Di Pasar Modal Syariah", Jurnal Istiqro: modal syariah seperti bagaimana langkah-langkah melakukan investasi, mecari lebih banyak informasi terkait investasi, produk-produk apa saja yang ditawarkan dalam investasi di pasar modal syariah serta kelebihan dan kekurangan dari produk investasi yang akan dipilih.

Bagi peneliti selanjutnya diharapkan menambahkan variabel-variabel penelitian yang tidak disebutkan dalam penelitian ini. Sebab, dalam penelitian ini hanya terdapat 2 variabel yaitu variabel persepsi dan variabel modal minimal yang memiliki pengaruh sebesar 68,4\% dan masih terdapat variabel lain sebesar $31,6 \%$ yang tidak dijelaskan dalam penelitian ini.

Jurnal Hukum Islam, Ekonomi Dan Bisnis, Vol. 5 no. 2 (July 2019). http:/ / ejournal.iaida.ac.id Hasibuan, Siti Rahma. "Minat Investasi Mahasiswa Untuk Berinvestasi Di Pasar Modal Syariah (Studi Kasus di Galeri Investasi UIN Sumatera Utara Periode 2017-2018)," Skripsi (Medan : UIN Sumatera Utara, 2018/2019),

http:/ / repository.uinsu.ac.id Iranati, Rahma Bellani Oktavindria. "Pengaruh Religiusitas, Kepercayaan, Pengetahuan, Dan Lokasi Terhadap Minat Masyarakat Menabung Di Bank Syariah (Studi Kasus Pada Masyarakat di Kota Tangerang Selatan)," Skripsi (Jakarta : UIN Syarif Hidayatullah Jakarta, 2017), http://repository.uinjkt.ac.id 
Jalil, A., \& Hamzah, S. A. (2020). PENGARUH BAGI HASIL DAN KEBUTUHAN MODAL TERHADAP MINAT UMKM MENGAJUKAN PEMBIAYAAN PADA LEMBAGA KEUANGAN SYARIAH DI KOTA PALU. Jurnal Ilmu Perbankan dan Keuangan Syariah, 2(2), 178-198.

Kaidah, Nur. "Pengaruh Persepsi Mahasiswa Tentang Investasi Terhadap Minat Investasi Saham Di Pasar Modal Syariah (Studi Kasus Pada Mahasiswa Angkatan 2015 Fakultas Ekonomi Dan Bisnis Islam Dan Fakultas Syariah Universitas Islam Negeri Raden Intan Lampung)", Skripsi (Lampung: Universitas Islam Negeri Raden Intan Lampung, 2018),

http:/ / repository.radenintan.ac.id

Kementrian Agama RI. Al-Qur'an Tajwid Kode, Transliterasi Per Kata, Terjemah Per Kata. (Bekasi: Cipta Bagus Segara, 2013).

Latifah, Siti. "Pengaruh Pengetahuan, Modal Minimal, Dan Motivasi Investasi Terhadap Minat Mahasiswa Untuk Berinvestasi Di Pasar Modal Syariah", http:// repository.iainpurwokerto. ac.id/5030/

Malik, Ahmad Dahlan. "Analisa FactorFaktor Yang Mempengaruhi Minat Masyarakat Berinvestasi Dipasar Modal Syariah Melalui Bursa Galeri Investasi UISI," Jurnal Ekonomi Dan Bisnis Islam, Vol. 3, No. 1, Januari- Juni 2017, 64-65. https://e-journal.unair.ac.id

Malkan, M., Kurniawan, I., Nurdin, N., \& Noval, N. (2021). Pengaruh
Pengetahuan Tentang Pasar Modal Syariah Terhadap Minat Investasi Saham di Pasar Modal Syariah Jurnal Ilmu Perbankan dan Keuangan Syariah, 3(1), 57-73.

Marzuki, M., \& Nurdin, N. (2020). The Influence of Halal Product Expectation, Social Environment, and Fiqih Knowledge on Intention to Use Shariah Financial Technology Products. International Journal of Innovation, Creativity and Change, 13(1), 171193.

Nandar, Haris, Mustafa Kamal Rokan, dan M. Ridwan, "Faktor Yang Mempengaruhi Minat Mahasiswa Berinvestasi di Pasar Modal Syariah Melalui Galeri Investasi IAIN Zawiyah Cot Kala Langsa," KITABAH, vol. 2 no. 2 (JuliDesember 2018), 188-189. https://www.google.com/

Nurdin, N. (2018). Institutional Arrangements in E-Government Implementation and Use: A Case Study From Indonesian Local Government. International Journal of Electronic Government Research (IJEGR), 14(2), 44-63. https:// doi.org/10.4018/ijegr.201 8040104

Nurdin, N., Azizah, W. N., \& Rusli, R. (2020). Pengaruh Pengetahuan,Kemudahan dan Risiko Terhadap Minat Bertransaksi Menggunakan Finansial Technology (Fintech) Pada Mahasiswa Institut Agama Islam Negeri (IAIN) Palu Jurnal Ilmu Perbankan dan Keuangan Syariah, 2(2), 199-222.

Nurdin, N., \& Yusuf, K. (2020). Knowledge management lifecycle 
in Islamic bank: the case of syariah banks in Indonesia. International Journal of Knowledge Management Studies, 11(1), 59-80. https:/ / doi.org/10.1504/ijkms.20 20.105073

Nurdin, N., Ningrum, R., Bachmid, S., \& Jalil, A. (2021). Pengaruh Manfaat, Kepercayaan dan Kemudahan Penggunaan Terhadap Minat Nasabah Menggunakan Mobile Banking di Bank Mega Syariah Cabang Palu Jurnal Ilmu Perbankan dan Keuangan Syariah, 3(1), 30-45.

Pardiansyah, Elif. “Investasi Dalam Perspektif Ekonomi Islam: Pendekatan Teoritis Dan Empiris," Economica: Jurnal Ekonomi Islam, vol.8 no. 2 (2017). https://journal.walisongo.ac.id/in dex.php/economica/article/view/ 1920

"Pasar Modal Syariah." Situs Resmi Otoritas Jasa Keuangan (OJK). https://ojk.go.id/id/kanal/syaria

h/Pages/Pasar-ModalSyariah.aspx

"Persepsi," Wikipedia Ensiklopedia Bebas.

https://id.wikipedia.org/wiki/Per sepsi Purboyo, Rizka Zulfikar dan Teguh Wicaksono, "Pengaruh Aktifitas Galeri

Investasi, Modal Minimal Investasi, Persepsi Resiko Dan Persepsi Return Terhadap Minat Investasi Saham Syariah (Studi Pada Mahasiswa Uniska MAB Banjarmasin)," Jurnal Wawasan Manajemen, vol. 7 no. 2 (2019). https://jwm.ulm.ac.id

Rusli, R., \& Nurdin, N. (2021). Understanding Indonesia millennia Ulama online knowledge acquisition and use in daily fatwa making habits. Education and Information Technologies.

https://doi.org/10.1007/s10639021-10779-7

Sakinah, "Investasi Dalam Islam," Iqtishadia : Jurnal Ekonomi Dan Perbankan Syariah, vol.1 no. 2 (Desember 2014), 255.

http:/ / ejournal.stainpamekasan.ac.id/i ndex.php/iqtishadia/article/view /483/469

"Salinan Peraturan Otoritas Jasa Keuangan." Situs Resmi Otoritas Jasa Keuangan(OJK).

https://www.ojk.go.id/id/regulasi/Do cuments/Pages/Persetujuan-BankUmum-Sebagai-

Kustodian/pojk\%2027-2019.pdf

"Sampel Statistika," Wikipedia Ensiklopedia Bebas.

https://id.wikipedia.org/wiki/Per sepsi

Sholahuddin, Muhammad. Lembaga Keuangan Dan Ekonomi Islam. Yogyakarta: Penerbit Ombak, 2014.

Soemitra, Andri. Bank Dan Lembaga Keuangan Syariah. Jakarta: Prenadamedia Group, 2009.

Sudaryono, metodologi Penelitian. Depok : RajaGrafindo Persada, 2013.

Sundari, Amalia. "Analisis Pengaruh Modal Minimal Dan Pemahaman Investasi Terhadap Minat Mahasiswa Berinvestasi Di Pasar Modal Ditinjau Dari Perspektif Ekonoomi Islam (Studi pada Mahasiswa Fakultas Ekonomi Dan Bisnis Islam UIN Raden Intan 
Lampung Angkatan Tahun 2014)," Skripsi (Lampung: UIN Raden Intan Lampung, 2019), http:/ / repository.radenintan.ac.id "Uji Multikolinearitas dengan Melihat Nilai Tolerance dan VIF SPSS," Situs
SPSSIndonesia.https://www.spssi ndonesia.com

https://journal.uii.ac.id/IUSTUM/articl e/view/4519/3987

"Yuk Nabung Saham," Situs Resmi Yuk Nabung Saham-IDX. http://yuknabungsaham.idx.co.id $\angle$ about-yns 